\title{
KONTRIBUSI MODEL PEMBELAJARAN PAKEM TERHADAP HASIL BELAJAR MATEMATIKA SISWA KELAS XI IPA SMA NEGERI 31 JAKARTA
}

\author{
Alberth Supriyanto Manurung \\ Surel : alberth_1303@yahoo.co.id
}

\begin{abstract}
The objective of the research is to determine the contribution learning model PAKEM with mathematic learning result. The study makes use of survey method which implements regression and contribution technique. The research was conducted at SMA 31 Jakarta, kecamatan Matraman, Jakarta Timur with $n=36$ using Cluster Sampling technique.The result of research show there is a positive contribution learning model PAKEM with mathematic learning result. Based on the result of research, the students mathematic learning result could be enhanced by increasing learning model PAKEM, since the result of verification simply be able to prove the learning model PAKEM to be significant determinant factors.
\end{abstract}

Keyword: learning model PAKEM, mathematic learning result and contribution

\begin{abstract}
ABSTRAK
Tujuan penelitian ini adalah untuk menentukan kontribusi model pembelajaran PAKEM terhadap hasil belajar matematika. Metode penelitian yang digunakan adalah metode survei dan mengunakan teknik analisis regresi dan korelasi sederhana. Penelitian ini dilakukan di SMA Negeri 31 Jakarta kecamatan Matraman, Jakarta Timur dengan $\mathrm{n}=36$ dengan menggunakan teknik Cluster Sampling. Hasil penelitian menunjukkan bahwa terdapat hubungan positif antara model pembelajaran PAKEM terhadap hasil belajar matematika. Berdasarkan hasil penelitian, hasil belajar matematika dapat ditingkatkan dengan mengunakan model pembelajaran PAKEM, karena hasil verifikasi membuktikan bahwa model pembelajaran PAKEM menjadi faktor-faktor penentu yang signifikan.
\end{abstract}

Kata kunci: model pembelajaran PAKEM, hasil belajar matematika dan kontribusi

\section{PENDAHULUAN}

Pembelajaran merupakan salah satu indikator penyelesaian masalah pendidikan dan merupakan jantung pendididkan, pembelajaran yang saat ini dikembangkan dan mulai menjadi acuan adalah pembelajaran aktif, kreatif, efektif dan menyenangkan. Pembelajaran ini memaksa peserta didik mengembangkan kreativitas sehingga benar-benar pembelajaran tersebut menyenangkan dan pada konteks ini pendidik berperan sebagai mentransferkan ilmu pengetahuan kepada peserta didik mulai dari mempermudah daya ingat sampai menemukan rumusan masalah.

Dalam hal ini banyak model pembelajaran yang dipergunakan untuk menyelesaikan masalah pendidikan dan salah satunya adalah model pembelajaran PAKEM yang pastinya akan mempengaruhi perkembangan dari anak yang mana setiap anak memiliki sifat yang 
berbeda-beda satu sama yang lain sehingga dapat menunjukkan karakter anak dalam menyelesaikan permasalahan yang dihadapi dan menurut beberapa ahli psikologi permasalahan diatas termasuk dalam perkembangan ilmu pengetahuan, hal ini dapat diamati melalui sikap yang mengambarkan aktualisasi anak tersebut. Manusia sebagai organisme yang memiliki dorongan untuk berkembang yang pada akhirnya menyebabkan ia sadar akan keberadaannya dan muncul sikap negatif terhadap kemampuan yang ia miliki sehingga memandang seluruh yang dikerjakan sebagai sesuatu yang sulit terselesaikan, sebaliknya untuk hal positif selalu memandang seluruh yang dikerjakan sebagai sesuatu yang amat mudah terselesaikan, secara umum model PAKEM jelas dipengaruhi oleh lingkungannya sehingga perlu kajian yang lebih dalam bagaimana menyikapi permasalahan.

$$
\text { Pada kesempatan yang }
$$

berbeda, belajar menurut Rogers dalam Syaiful adalah kebebasan dan kemerdekaan mengetahui apa yang baik apa yang buruk, anak dapat melakukan pilihan tentang apa yang dilaksanakan dengan penuh tanggung jawab. Ada pengertian bahwa belajar adalah penambahan pengetahuan dan yang lain mengatakan bahwa belajar adalah berubah, dalam hal ini belajar merupakan usaha mengubah tingkah laku. Jadi belajar akan membawa dampak perubahan pada individu yang mau belajar. Perubahan tidak sekedar penambahan ilmu pengetahuan tetapi bentuk kecakapan, keterampilan, sikap, pengertian harga diri, minat, watak dan penyesuaian diri. Jelasnya mengandung semua aspek organisasi dan tingkah laku pribadi seseorang dengan demikian dapat dikatakan bahwa belajar itu sebagai rangkaian kegiatan jiwa raga, psiko-fisik untuk menuju perkembangan pribadi manusia seutuhnya, yang berarti menyangkut unsur cipta, rasa, karsa, ranah kognitif, afektif, dan psikomotorik.

Pada kesempatan yang berbeda menurut Dale. Belajar merupakan proses yang berlangsung dalam jangka waktu yang lama melalui latihan dan pengalaman yang membawa perubahan diri dan perubahan cara mereaksi terhadap suatu perangsang tertentu. Pembelajaran yang bermakna akan terasa jika memiliki kaitan dengan keutuhan seseorang dan memiliki keterlibatan personal (perasaan pembelajar) yang diawali dari diri sendiri (dorongan belajar berasal dari dalam diri), meresap (mempengaruhi sikap, perilaku, perilaku, dan kepribadian pembelajar) dan dievaluasi.

Belajar selalu berkenaan dengan perubahan tingkah laku dipelajari melalui psikologi. Teori hasil belajar matematika banyak dikemukakan para ahli pendidikan, menurut Suryabratha hasil belajar adalah hasil saat belajar yang berupa penilaian yang berbentuk angka atau symbol. Para siswa diajak untuk mengkaji ulang segala pengetahuan yang di dapat di kelas sehingga proses 
belajar dapat tercapai. Hasil belajar matematika pada dasarnya adalah hasil yang dicapai dalam usaha penguasaan materi dan ilmu pengetahuan yang merupakan suatu kegiatan yang menuju terbentuknya kepribadian seutuhnya. Melalui belajar dapat diperoleh hasil yang lebih baik. Pola tingkah laku manusia tersebut tersusun menjadi suatu model sebagai prinsip-prinsip belajar diaplikasikan ke dalam matematika. Prinsip belajar ini haruslah dipilih sehingga cocok untuk mempelajari matematika. Matematika yang berkenaan dengan ide-ide abstrak yang diberi simbol dan tersusun secara hirarkis dan penalarannya deduktif, jelas belajar matematika itu memerlukan kegiatan mental yang tinggi.

Dari beberapa pendapat para ahli di atas maka dapat disimpulkan bahwa hasil belajar matematika dapat didefenisikan kemampuan atau pengetahuan siswa yang diperoleh melalui proses pembelajaran matematika selama kurun waktu tertentu sehingga menimbulkan daya pikir, daya nalar, berpikir logika, dan sistematis.

PAKEM merupakan strategi pembelajaran untuk mengembangkan keterampilan dan pemahaman siswa dengan penekanan pada belajar sambil beraktivitas. Dalam PAKEM pendidik mengunakan berbagai sumber belajar untuk mencapai tujuan pembelajaran yang telah ditetapkan kurikulum, harapan yang terbesar adalah pendidik perlu memuat langkah-langkah yang lebih efesien dengan mulai dari perencanaan, strategi, persiapan materi dan metode pembelajaran sampai memberikan evaluasi pada siswa.

Belajar aktif memiliki keunggulan yang sangat besar, hal ini terjadi proses perkembangan siswa yang diawali merangakai kata-kata menuju kalimat yang siswa pikirkan melalui pengalaman dan sumber informasi dari berbagai sumber yang selalu dilakukan siswa sehingga muncul rasa tanggung jawab serta adanya inisiatif yang berakibat munculnya rasa haus akan belajar dan pelan-pelan mengurangi ketergantungan kepada pendidik atau orang lain bila mereka baru mempelajari hal yang baru. Banyak cara menemukan ciri-ciri siswa yang belajar secara aktif dan tergantung pada karakter siswa yang dapat dilihat rasa penasaran siswa terhadap hal yang baru siswa perhatikan sehingga membuat siswa berpikir kritis dalam menghadapi masalah.

Siswa yang belajar akan mengalami perubahan, misalkan sebelum belajar kemampuannya hanya $20 \%$ maka setelah mentransfer model PAKEM selama paling sedikit satu semester diharapkan menjadi $100 \%$, sehingga akan berakibat efek domino yang salah satunya meningkatkan rasa kepercayaan diri siswa dalam pembelajaran yang dijalani siswa. 
Alberth Supriyanto Manurung : Konstribusi ...

\begin{tabular}{|c|c|c|}
\hline No & Aktivitas guru & Pembelajaran \\
\hline 1 & $\begin{array}{l}\text { Guru mengunakan alat bantu dan } \\
\text { sumber belajar yang beragam }\end{array}$ & $\begin{array}{l}\text { Sesuai mata pelajaran guru mengunakan: } \\
\text { a. Alat yang tersedia atau dibuat sendiri } \\
\text { b. Gambar } \\
\text { c. Studi kasus } \\
\text { d. Nara sumber } \\
\text { e. Lingkungan }\end{array}$ \\
\hline 2 & $\begin{array}{l}\text { Guru memberi kesempatan } \\
\text { kepada siswa untuk dapat } \\
\text { mengembangkan keterampilan }\end{array}$ & $\begin{array}{l}\text { a. Siswa melakukan percobaan, pengamatan } \\
\text { atau wawancara } \\
\text { b. Siswa mengumpulkan data atau jawaban } \\
\text { dan mengolahnya sendiri } \\
\text { c. Siswa menarik kesimpulan } \\
\text { d. Siswa memecahkan masalah dan mencari } \\
\text { rumus sendiri } \\
\text { e. Siswa menulis laporan atau hasil karya } \\
\text { lain dengan kata-kata sendiri }\end{array}$ \\
\hline 3 & $\begin{array}{l}\text { Guru memberi kesempatan } \\
\text { kepada siswa untuk mengungkap } \\
\text { gagasannya sendiri secara lisan } \\
\text { maupun tulisan }\end{array}$ & $\begin{array}{l}\text { melalui: } \\
\text { a. Diskusi } \\
\text { b. Pertanyaan terbuka } \\
\text { c. Hasil karya }\end{array}$ \\
\hline 4 & $\begin{array}{l}\text { Guru menyesuaikan bahan dan } \\
\text { kegiatan belajar dengan } \\
\text { kemampuan siswa }\end{array}$ & $\begin{array}{l}\text { a. Siswa dikelompakkan sesuai dengan } \\
\text { Kemampuan } \\
\text { b. Bahan pelajaran disesuaikan dengan } \\
\text { kemampuan kelompok tersebut } \\
\text { c. Pemberian tugas perbaikan dan } \\
\text { Pengayaan } \\
\end{array}$ \\
\hline 5 & $\begin{array}{l}\text { Guru mengaitan pembelajaran } \\
\text { dengan pengalaman siswa sehari- } \\
\text { Hari }\end{array}$ & $\begin{array}{l}\text { a. Siswa menceritakan atau memanfaatkan } \\
\text { pengalaman sendiri } \\
\text { b. Siswa menerapkan hal yang dipelajari } \\
\text { dalam kehidupan sehari-hari }\end{array}$ \\
\hline 6 & $\begin{array}{l}\text { Guru menilai pembelajaran dan } \\
\text { kemajuan belajar siswa secara } \\
\text { terus menerus }\end{array}$ & $\begin{array}{l}\text { a. Guru memantau kerja siswa } \\
\text { b. Guru memberikan umpan balik }\end{array}$ \\
\hline
\end{tabular}




\section{METODE PENELITIAN}

Penelitian ini mengunakan metode survei dengan teknik korelasi yakni untuk mengetahui kontribusi antara model pembelajaran aktif, kreatif, efektif, dan menyenangkan dengan hasil belajar Matematika. Korelasi adalah salah satu teknik analisis statistik yang paling banyak digunakan oleh para peneliti. Karena peneliti umumnya tertarik pada peristiwa-peristiwa yang terjadi dan mencoba untuk mengali dan menghubungkannya.

Populasi penelitian ini adalah siswa kelas XI SMA Negeri 31 di Kecamatan Matraman, Jakarta Timur, dalam hal ini mengambil populasi dari SMA Negeri 31 di kecamatan Matraman yang memiliki karakteristik dan kebiasaan siswa yang sama. Secara teori Populasi dapat diartikan semua nilai baik hasil perhitungan maupun pengukuran, baik kuantitatif maupun kualitatif, dari karekteristik tertentu mengenai sekelompok objek yang lengkap dan jelas. Sampel dalam penelitian ini adalah siswa kelas XI IPA SMA Negeri 31 yang diambil dengan mengunakan teknik Cluster Sampling. Dalam Cluster Sampling proses pengambilan sampel dengan cara memilih satu SMA Negeri dari tiga SMA Negeri yang mewakili satu kecamatan yang mempunyai karakteristik yang sama diantara SMA untuk dipilih menjadi sampel.

Teknik pengumpulan data merupakan suatu prosedur yang sistematis dan standar untuk memperoleh data yang diperlukan.
Dalam suatu penelitian perlu memilih teknik pengumpulan data yang relevan untuk menjawab pokok permasalahan penelitian dan mencapai tujuan penelitian. Adapun beberapa tahapan yang ditempuh dalam proses pengumpulan data dalam penelitian adalah penentuan alat pengumpul data, alat yang digunakan untuk memperoleh data dalam penelitian hendaknya relevan dengan pertimbangan segi kepraktisan, efesiensi dan keandalan alat tersebut. Tahap yang lain dalam penyusunan data adalah setelah menentukan alat pengumpulan data, maka langkah selanjutnya adalah menyusun alat pengumpulan data agar valid dan reliabel. Untuk itu prosedur yang akan dilakukan adalah sebagai berikut: (1) Menentukan variabel-variabel vang akan diteliti yaitu variabel (X) model PAKEM dan variabel Y hasil belajar matematika, (2) Menentukan indikator dari masing-masing variabel tersebut dan mengidentifikasi sub indikatornya, yaitu variabel (X) model PAKEM dan variabel $\mathrm{Y}$ hasil belajar matematika dengan beberapa indikator seperti yang telah disebutkan sebelumnya, (3) Menyusun kisi-kisi soal, (4) Menyusun pertanyaan dari variabel yang disertai jawaban, Menetapkan kriteria penskoran untuk setiap jawaban, dengan lima alternatif jawaban untuk soal tes.

Instrumen penelitian ini adalah untuk memaparkan instrumen yang digunakan sesuai dengan variabel yang telah ditetapkannya. Instrumen variabel yang ditetapkan 
perlu adanya uji coba instrumen. Uji coba instrumen ini dimaksudkan adalah untuk mengetahui validitas reliabilitas soal serta butir-butir yang digunakan.

Data yang telah diperoleh dianalisis dengan bantuan komputer program Ms. Excel, untuk mendapatkan mean, median, modus, standar deviasi, range, distribusi frekuensi serta penyajian grafik histogram dari data setiap variabel terikat maupun bebas dalam penelitian.

Langkah selanjutnya adalah melakukan pengujian normalitas data, uji normalitas data dilakukan terhadap galat taksiran regresi $\hat{Y}$ atas $\mathrm{X}$ dengan menggunakan statistik inferensial yaitu Lillefors. Dengan ketentuan apabila hasil analisis $\mathrm{L}_{\text {hitung }}$ $<\mathrm{L}_{\text {tabel }}$ maka Ho diterima yang berarti sampel berdistribusi normal.

Setelah sampel berdistribusi normal dilanjutkan menghitung koefisien korelasi sederhana antar variabel menggunakan rumusan koefisien parsial dengan uji-t, dengan ketentuan $\mathrm{t}$ hitung $>\mathrm{t}$ tabel, maka koefisisen korelasi signifikan.

Dalam langkah selanjutnya Hipotesis diuji menggunakan korelasi dan regresi sederhana. Korelasi sederhana digunakan untuk mengetahui tingkat hubungan antara variabel bebas dan variabel terikat, sedangkan regresi sederhana digunakan jika variabel terikat (dependen Variabel) tergantung pada suatu variabel bebas (indenpenden variabel). Model regresi sederhana dapat dijelaskan melalui rumusan.

$$
\gamma=\beta_{0}+\beta_{1} \chi
$$

Dimana:

$\gamma=$ Hasil belajar Matematika

$\beta_{0}=$ Nilai konstanta

$\beta_{1}=$ Nilai koefisien regresi

$\chi=$ Model PAKEM

\section{Hipotesis Statistik}

Hipotesis pertama : $\mathrm{H}_{0}: \rho_{\mathrm{y} 1} \leq 0$

$: \mathrm{H}_{1}: \rho_{\mathrm{y} 1}>0$

Keterangan:

$\rho_{\mathrm{y} 1}=$ koefisien korelasi antara model PAKEM dan hasil belajar matematika

Bagan alir penelitian yang meliputi tahapan penelitian yang akan dilaksanakan dapat dilihat pada Gambar berikut. 


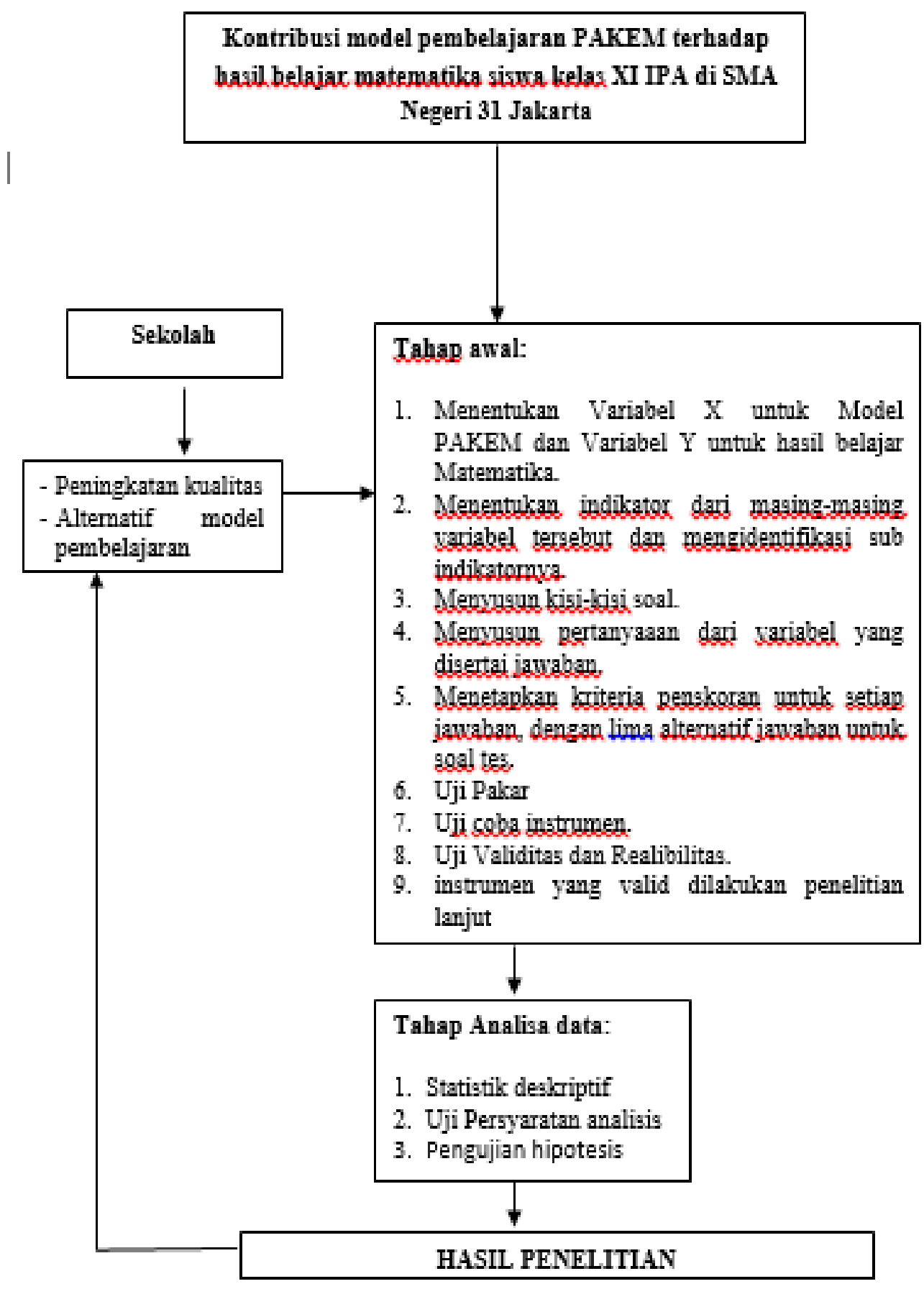

Gambar Proses dan Tahapan Penelitian 
HASIL PENELITIAN DAN PEMBAHASAN

Uji coba angket variabel Hasil

Belajar Matematika berikut dilakukan pada 36 orang responden dari kelas XI IPA SMA NEGERI 31 JAKARTA. Dari data skoring setelah dilakukan maka uji validitas item angket Hasil Belajar Matematika menggunakan uji Point Biserial.

Hasil pengujian instrumen pada responden menunjukkan bahwa pada tingkat signifikan 5\% sejumlah instrumen yang digunakan dalam penelitian ini diperoleh nilai koefisien korelasi lebih besar dari nilai r-tabel Uji Point Biserial. sebesar 0.32 untuk $\mathrm{N}=36$. Dengan cacatan dari 36 item hanya 5 iem yang mengalami drop dan yang lain dapat dikatakan bahwa instrumen dalam penelitian ini adalah valid atau dapat mengukur variabel yang diteliti.

Reliabilitas adalah alat yang digunakan untuk mengetahui tingkat keandalan dari alat ukur yang dipakai semakin tinggi nilai reliabilitas atau data tersebut telah reliabel maka alat ukur yang dipakai juga lebih baik (andal) untuk digunakan dalam penelitian selanjutnya atau tempat (lokasi) yang berbeda.

Tabel Reliabilitas dari Hasil Belajar Matematika

\begin{tabular}{|c|c|c|}
\hline Variabel & $\mathrm{r}$ & Keterangan \\
\hline $\begin{array}{c}\text { Hasil } \\
\text { Belajar }\end{array}$ & 0,8509 & Reliabel \\
\hline
\end{tabular}

Hasil pengujian reliabilitas pada tabel 1 di atas menunjukkan bahwa nilai koefisien reliabilitas variabel yang digunakan, dalam variabel di atas lebih besar dari nilai r-tabel, maka hasil jawaban responden dapat diandalkan dengan kata lain bahwa apabila dilakukan penelitian yang sama dalam waktu yang berbeda maka responden akan memberikan jawaban yang sama.

$$
\text { Data hasil belajar }
$$

matematika diperoleh melalui tes dengan 25 butir pertanyaan dengan 36 responden. Setiap butir pertanyaan yang dijawab dengan benar diberi skor 1 dan yang salah diberi skor 0 , sehingga rentang skor teoretik adalah antara 0 sampai dengan 25 . Berdasarkan data observasi yang terkumpul diperoleh skor maksimum 21 dan skor minimum 2, rentang empirik antara 2 - 21, rata-rata 10,1667, Simpangan baku (SD) 4,65, Modus (Mo) 6,47, Median (me) 9,5 dan Varian atau ragam 21,65.

Jika skor hasil belajar siswa kelas XI IPA SMA Negeri 31 Jakarta dianalisis dengan menggunakan persentase pada distribusi frekuensi maka dapat dibuat table distribusi frekuensi berikut: 
Tabel Distribusi Frekuensi Skor Hasil Belajar Matematika

\begin{tabular}{|c|c|c|c|c|c|}
\hline $\begin{array}{c}\text { Nilai } \\
\text { Matematika }\end{array}$ & $\mathrm{f}_{\mathrm{i}}$ & $\begin{array}{c}\text { Nilai } \\
\text { tengah }\end{array}$ & $\mathrm{f}_{\mathrm{k}}$ & $\mathrm{f}_{\mathrm{r}} \%$ & $\mathrm{f}_{\mathrm{i}} \mathrm{X}$ \\
\hline $2 .-4$ & 2 & 3 & 2 & 5,555556 & 6 \\
\hline $5 .-7$ & 12 & 6 & 14 & 33,33333 & 72 \\
\hline $8 .-10$ & 6 & 9 & 20 & 16,66667 & 54 \\
\hline $11 .-13$ & 8 & 12 & 28 & 22,22222 & 96 \\
\hline $14 .-16$ & 4 & 15 & 32 & 11,11111 & 60 \\
\hline $17 .-19$ & 2 & 18 & 34 & 5,555556 & 36 \\
\hline $20 .-22$ & 2 & 21 & 36 & 5,555556 & 42 \\
\hline
\end{tabular}

Pada tabel 2 nampak bahwa sebanyak 6 orang $(16,67 \%)$ responden berada pada kelompok rata-rata, sebanyak 16 orang $(44,44 \%)$ responden berada diatas kelompok rata-rata, dan sebanyak 14 orang $(38,8 \%)$ responden berada dibawah kelompok rata-rata.

Data model pembelajaran PAKEM diperoleh melalui kuesioner dengan 22 butir pernyataan dengan 36 Responden. Pemberian skor dilakukan dengan skala Likert, menggunakan lima alternatif jawaban, yaitu: Sangat sering, Sering, Kadang-kadang, Jarang dan Tidak pernah. Rentang skor teoretik adalah antara 22 sampai dengan 220. Berdasarkan data observasi yang terkumpul diperoleh skor maksimum 96 dan skor minimum 63, rentang empirik antara 63 - 96, rata-rata 81,667, Simpangan baku (SD) 8,22, Modus (Mo) 77,93, Median (me) 80,07 dan Varian 67,60. Distribusi variabel Model pembelajaran PAKEM disajikan pada tabel berikut:

Tabel Distribusi frekuensi Skor Model pembelajaran PAKEM

\begin{tabular}{|c|c|c|c|c|c|}
\hline Model PAKEM & $\mathrm{f}_{\mathrm{i}}$ & Nilai tengah & $\mathrm{f}_{\mathrm{k}}$ & $\mathrm{f}_{\mathrm{r}} \%$ & $\mathrm{f}_{\mathrm{i}} \mathrm{X}$ \\
\hline $63-68$ & 3 & 65,5 & 3 & 8,33333333 & 196,5 \\
\hline $69-74$ & 2 & 71,5 & 5 & 5,55555556 & 143 \\
\hline $75-80$ & 14 & 77,5 & 19 & 38,8888889 & 1085 \\
\hline $81-86$ & 5 & 83,5 & 24 & 13,8888889 & 417,5 \\
\hline $87-92$ & 8 & 89,5 & 32 & 22,2222222 & 716 \\
\hline $93-98$ & 4 & 95,5 & 36 & 11,1111111 & 382 \\
\hline
\end{tabular}

Pada tabel di atas nampak bahwa sebanyak 5 orang $(13,89 \%)$ responden berada pada kelompok rata-rata, sebanyak 12 orang $(33,3 \%)$ responden berada diatas kelompok rata-rata, dan sebanyak 19 orang 
$(52,78 \%)$ responden berada dibawah kelompok rata-rata.

Uji normalitas data dilakukan terhadap galat taksiran regresi $\hat{Y}$ atas $\mathrm{X}$ dengan menggunakan statistik inferensial yaitu Lillefors. Rincian setiap hasil pengujian normalitas data penelitian adalah seperti berikut:

Untuk persamaan regresi umum $\hat{\mathrm{Y}}=\mathrm{a}+\mathrm{bX}$ diperoleh $\mathrm{a}=-8,74$ dan slope $b=0,23$ oleh karena itu persamaan regresi umum $\hat{Y}=-8,74+$ $0,23 X$. Pengujian galat taksiran regresi $\hat{Y}$ atas $X$ menghasilkan $L_{\text {hitung }}$ maksimum sebesar 0,078. Adapun $\mathrm{L}_{\text {tabel }}$ pada taraf nyata $\alpha=0,05$ diperoleh nilai sebesar 0,147. Dari hasil perbandingan antara $L_{\text {hitung }}$ dan $\mathrm{L}_{\text {tabel }}$ ternyata $\mathrm{L}_{\text {hitung }}<\mathrm{L}_{\text {tabel }}$ yaitu $0,078<0,147$, dari hasil tersebut $\mathrm{H}_{\mathrm{o}}$ diterima dan dapat disimpulkan bahwa galat taksiran regresi $\hat{Y}$ atas $\mathrm{X}$ berdistribusi normal.

Setelah persyaratan analisis data terpenuhi, dilakukan analisis inferensial untuk menguji hipotesis yang dilakukan untuk menarik kesimpulan apakah Hipotesis penelitian yang telah dirumuskan didukung oleh data empirik yang diperoleh.

Pengujian hipotesis penelitian ini mengunakan rumusan regresi dan korelasi. Hipotesis dianalisis dengan rumusan regresi dan korelasi sederhana, rincian hasil pengujian sebagai berikut: pengujian analisis regresi serhana meliputi uji signifikansi regresi dan uji linieritas regresi yang dilakukan dengan uji F. Sedangkan pengujian analisis korelasi sederhana adalah berupa uji signifikansi korelasi menggunakan uji t. Teknik korelasi sederhana yang digunakan adalah Product Person Moment.

Rumusan hipotesis penelitian adalah terdapat kontribusi positif antara Model Pembelajaran PAKEM (X) dan Hasil Belajar Matematika (Y). Dari hasil analisis regresi diperoleh bahwa kontribusi antara Model Pembelajaran PAKEM (X) dan hasil belajar matematika (Y) digambarkan dengan persamaan $\hat{\mathrm{Y}}=-8,739+0,231 \mathrm{X}$. Untuk mengetahui model persamaan regresi diatas signifikan atau tidak dilakukan uji signifikansi dan linieritas regresi dengan analisis varians. Rangkuman hasil perhitungan uji signifikansi dan linieritas regresi antara Model Pembelajaran PAKEM (X) dan hasil belajar matematika (Y) seperti tampak pada tabel di bawah ini:

Tabel Rangkuman uji Linieritas dan Signifikansi Regresi Y atas X

\begin{tabular}{|l|c|c|c|c|c|}
\hline Sumber Varians & Db & JK & RJK & $\mathrm{F}_{\text {hitung }}$ & $\mathrm{F}_{\text {tabel }}(0,05)$ \\
\hline Total & 36 & 4582 & & & \\
\hline Regresi (a) & 1 & 3802,77 & 3802,77 & & \\
\hline
\end{tabular}


SEJ VOLUME 7 NO. 3 DESEMBER 2017

\begin{tabular}{|l|c|c|c|c|c|}
\hline Regresi (b/a) & 1 & 130,27 & 130,27 & 6,82 & 4,13 \\
\hline Residu (s) & 34 & 648,95 & 19,08 & & \\
\hline Tuna Cocok (TC) & 14 & 313,12 & 23,36 & 1,33 & 2,23 \\
\hline Kekeliruan (G) & 20 & 335,8333 & 16,79 & & \\
\hline
\end{tabular}

Keterangan : Regresi signifikan $\left(\mathrm{F}_{\text {hitung }}=6,82>\mathrm{F}_{\text {tabel }}=4,13\right)$

: Regresi linier $\left(\mathrm{F}_{\text {hitung }}=1,33<\mathrm{F}_{\text {tabel }}=2,23\right)$

Dari tabel di atas tersebut disimpulkan bahwa korelasi Model Pembelajaran PAKEM dan hasil belajar matematika signifikan dan linier, artinya persamaan regresi $\hat{Y}=$ $8,739+0,231 X$. dapat digunakan sebagai alat untuk menjelaskan dan mengambil kesimpulan mengenai kontribusi Model Pembelajaran PAKEM dan hasil belajar Matematika.

Selanjutnya dilakukan pengujian korelasi dengan Product Person Momen untuk mengetahui kekuatan kontribusi antara variabel Model Pembelajaran PAKEM dan variabel hasil belajar matematika. Dari hasil perhitungan didapat koefisien korelasi sebesar $\quad r_{\mathrm{xy}}=$ 0,409. Uji keberartian koefisien korelasi dengan uji t diperoleh harga $t_{\text {hitung }}$ sebesar 2,61 sedangkan $t_{\text {tabel }}$ pada taraf signifikan $\alpha=0,05$ dengan derajat kebebasan 34 diperoleh harga $\mathrm{t}_{\text {tabel }}=1,69$ Kekuatan kontribusi variabel $\mathrm{X}$ dengan $\mathrm{Y}$ ditunjukkan dengan koefisien korelasi dan hasil uji t dapat dijelaskan bahwa korelasi sangat signifikan $\left(t_{\text {hitung }}>t_{\text {tabel }}\right)=$ korelasi berarti.
Dari hasil perhitungan didapat koefisien korelasi sebesar $r_{x y}=0,409$ didapat koefisien Determinasi sebesar 0,1672 , menerangkan bahwa $16,72 \%$ variansi variabel hasil belajar matematika dijelaskan atau ditentukan oleh Model Pembelajaran PAKEM. Dari hasil perhitungan analisis diatas dapat disimpulkan bahwa terdapat hubungan yang positif antara variabel Model Pembelajaran PAKEM dan variabel hasil belajar matematika.

Hal ini memberikan indikasi bahwa pendekatan PAKEM dapat digunakan untuk meningkatkan hasil belajar Matematika karena pendekatan PAKEM merupakan suatu pendekatan yang dapat melibatkan siswa secara aktif dalam pembelajaran dan dapat menstimulasi siswa untuk mengembangkan gagasannya sendiri dengan memanfaatkan sumber belajar yang ada sehingga siswa tidak hanya sebatas mengenal dan memahami, tapi mampu melaksanakan, menganalisis, dan mengevaluasi. 
Alberth Supriyanto Manurung : Konstribusi ...

\section{SIMPULAN}

Berdasarkan pada analisis deskriptif dapat disimpulkan bahwa skor rata-rata hasil belajar matematika siswa kelas XI IPA SMA Negeri 31 Jakarta dengan pendekatan PAKEM adalah 10,167 dan Simpangan baku (SD) 4,65 yang menunjukkan terjadinya kontribusi Model Pembelajaran PAKEM dan hasil belajar matematika.

Berdasarkan analisis inferensial dapat disimpulkan bahwa Model Pembelajaran PAKEM dengan hasil belajar matematika memiliki koefisien korelasi sebesar $r_{x y}=0,409$ dan koefisien Determinasi sebesar 0,1672, menerangkan bahwa $16,72 \%$ variansi variabel hasil belajar matematika dijelaskan atau ditentukan oleh Model Pembelajaran PAKEM. Dengan demikian hipotesis penelitian yang menyatakan terdapat kontribusi positif antara variabel Model Pembelajaran PAKEM dengan hasil belajar matematika secara statistik teruji kebenarannya. Dengan demikian dapat dikemukakan bahwa pendekatan Model Pembelajaran PAKEM merupakan salah satu alternatif upaya yang dapat digunakan untuk meningkatkan hasil belajar Matematika.

\section{DAFTAR RUJUKAN}

Dale, H. Schunk. 2012. Learning Theories an Education Perspective. Yogyakarta: Pustaka Pelajar.

Dimyanti dan Mudjiono. 2009. Belajar dan Pembelajaran. Jakarta: Departemen Pendidikan \& Kebudayaan dan Rineka Cipta,

Jess, F., Gregory, J. F. 2008. Theories of Personality. New York: McGraw Hill.

Manurung, Alberth. 2015. EDUSCIENCE Vol. 1, No. 1. Jakarta: FKIP UEU.

Sagala, Syaiful. 2012. Konsep dan Makna Pembelajaran. Bandung: Alfabeta.

Sardiman A. M. 2011. Interaksi \& Motivasi Belajar Mengajar. Jakarta: Rajawali Pers.

Slameto. 2010. Belajar \& FaktorFaktor yang mempengaruhi. Jakarta: Rineka Cipta.

Sugiyono. 2010. Statistika untuk penelitian. Bandung: Alfabeta.

Yudhawati, Ratna, dan Dany Haryanto. 2011. Teori-Teori Dasar Psikologi Pendidikan. Jakarta: P.T Prestasi Pustakaraya. 